\title{
List of Charts
}

Imperial Japanese Army Command Structure,

Southeast Asia, 1942-45

Sixteenth Army Command Structure, Java

Military Police Corps (Kenpeitai), Jakarta and Yogyakarta, 1942-45

Police Organization, Jakarta and Yogyakarta, 1942-45 201

Sixteenth Army Special Intelligence Section (Beppan) 210

Sixteenth Army Order of Battle, 1945

Sixteenth Army Senior Staff Officers and Special Units, 1945 